\title{
Penentuan Arah Kiblat Secara Partisipatif di Kampung Pasir Panjang
}

\author{
Farouki Dinda Rassarandi ${ }^{{ }^{*}}$, Siti Noor Chayati ${ }^{1}$, Oktavianto Gustin ${ }^{1}$, Luthfiya Ratna Sari ${ }^{1}$, \\ Sudra Irawan ${ }^{1}$, Arif Roziqin ${ }^{1}$, Wenang Anurogo ${ }^{1}$, M. Zainuddin Lubis ${ }^{1}$, Nur Cahyono \\ Kushardianto $^{2}$, Dodi Prima Resda ${ }^{2}$, Agung Riyadi $^{2}$, Supardianto $^{2}$, Sandi Prasetyaningsih ${ }^{2}$, \\ Condra Antoni ${ }^{2}$, Rizki Widi Pratama ${ }^{1}$, Rizki Irianto ${ }^{1}$, Dicki Prayogi ${ }^{1}$, Rizwan Bin \\ Khamis ${ }^{1}$, Bintang Budhiman ${ }^{1}$ \\ ${ }^{1}$ Program Studi Teknik Geomatika, Jurusan Teknik Informatika, Politeknik Negeri Batam \\ Jalan Ahmad Yani, Kota Batam, Indonesia \\ 2 Jurusan Teknik Informatika, Politeknik Negeri Batam \\ Jalan Ahmad Yani, Kota Batam, Indonesia \\ Email:*farouki@polibatam.ac.id
}

\begin{abstract}
Qibla is the center of direction for Muslims in performing prayer services. In equatorial regions such as Indonesia, an error in determining the Qibla direction of just $1^{\circ}$ can make the direction deviate as far as $111 \mathrm{~km}$ from the Kaaba. This community service activity aims to socialize the method of determining the direction of Qibla with mapping survey technology, namely Total Station, as well as together with the local community to carry out measurement activities in the field.

Community service activities are carried out in two stages, namely preparation and implementation in the field. By using the principle of calculating the spherical triangle in Geodesy Mathematics and utilizing the development of accurate positioning technology, the Total Station and compass are used to measure the Qibla direction after previously correcting the true north with the help of celestial bodies such as the sun. Thus, the measurement results obtained will have good accuracy.

From the measurement of the Qibla direction that has been done at the Nurus Sabil mosque, the angle of Qibla direction from north to west is obtained by $66^{\circ} 50^{\prime} 59.83^{\prime \prime}$ or compass azimuth of $293^{\circ}$ 9' 0.17 ". Based on the results of these calculations there are differences in the azimuth of $12^{\circ}$ from the azimuth / direction of the mosque's initial Qibla there. This happens because indeed the mosque from its inception has never been carried out the determination and confirmation of the direction of Qibla carefully and officially.
\end{abstract}

Keywords—qibla, true north, spherical triangle, Total Station

Abstrak - Kiblat merupakan pusat arah bagi Umat Muslim dalam mengerjakan ibadah sholat. Di daerah khatulistiwa seperti Indonesia, kesalahan penentuan arah kiblat sebesar $1^{\circ}$ saja dapat menjadikan arahnya menyimpang sejauh $111 \mathrm{~km}$ dari Ka'bah. Kegiatan pengabdian ini bertujuan untuk mensosialisasikan metode penentuan arah kiblat secara teliti dengan teknologi survei pemetaan, yaitu Total Station, sekaligus bersama-sama dengan masyarakat setempat melakukan kegiatan pengukuran di lapangan.

Kegiatan pengabdian dilaksanakan dalam dua tahap yaitu persiapan (pra pelaksanaan) dan pelaksanaan di lapangan. Dengan menggunakan prinsip perhitungan segitiga bola dalam ilmu Matematika Geodesi dan memanfaatkan perkembangan teknologi penentuan posisi secara akurat, Total Station dan kompas digunakan untuk mengukur arah kiblat setelah sebelumnya dilakukan koreksi arah utara sejati dengan bantuan benda langit seperti matahari. Dengan demikiran, hasil pengukuran yang didapatkan akan memiliki akurasi yang baik.

Dari pengukuran arah kiblat yang telah dilakukan di masjid Nurus Sabil, diperoleh sudut arah kiblat dari utara ke barat sebesar $66^{\circ} 50$ ' 59.83" atau azimuth kompas sebesar $293^{\circ} 9^{\prime}$, 0.17 ". Berdasarkan hasil perhitungan tersebut terdapat perbedaan azimuth sebesar $12^{\circ}$ dari azimuth/ arah kiblat awal masjid disana. Hal ini terjadi karena memang masjid tersebut dari awal berdirinya belum pernah dilakukan penetapan dan penegasan arah kiblat secara teliti dan resmi.

Kata Kunci- kiblat, utara sejati, segitiga bola, Total Station. 


\section{Pendahuluan}

Kecamatan Galang terbentuk berdasarkan UU No. 53 Tahun 1999 yang ditetapkan pada tanggal 4 Oktober 1999 dan aktivitas pemerintahan secara efektif dijalankan setelah dilantiknya Camat Galang dengan Surat Keputusan Walikota Batam No. Kpts. 02/II/2000 tanggal 2 Maret 2000. Sebelum tergabung dengan pemerintah Kota Batam, awalnya terdiri dari 10 Desa (Desa Pulau Abang, Karas, Sijantung, Sembulang, Rempang, Pangkil, Pengujan, Penaga, Tembeling dan Bintan Buyu) dengan luas wilayah mencapai $\pm 1.078,25 \mathrm{Km}^{2}$ (BPS Kota Batam, 2018). Setelah bergabung dengan pemerintah Kota Batam maka sebagian dari wilayah lama ada yang tetap bertahan pada induk pemerintahan yang lama dan yang masih menjadi bagian Kecamatan Galang ialah Pulau Abang, Karas, Sijantung, Sembulang dan Rempang ditambah lagi dengan Air Raja dan Subang Mas. Seiring dengan terbentuknya Kelurahan Galang Baru sebagai pecahan dari Pulau Abang dan Karas, maka jumlah Kelurahan yang ada sekarang menjadi 8 Kelurahan.

Menurut data dari BPS (Badan Pusat Statistik) Kota Batam (2018), pada tahun 2017 penduduk di Kecamatan Galang sebagian besar memeluk agama Islam, yaitu sebanyak 14.336 jiwa atau sekitar 89,98\% dari seluruh penduduk yang ada di Kecamatan Galang. Jumlah tempat peribadatan untuk muslim mencapai 63 bangunan, dimana 44 diantaranya berupa masjid dan 19 diantaranya merupakan mushola atau surau. Rempang Cate, salah satu kelurahan di Kecamatan Galang memiliki 11 masjid dan 4 mushola, beberapa diantaranya terdapat di Desa Pasir Panjang. Dari hasil kunjungan Tim Politeknik Negeri Batam, didapatkan gambaran di lapangan bahwa mushola atau masjid di Desa Pasir Panjang masih menggunakan arah kiblat sesuai dengan arah bangunan. Dengan kata lain, belum pernah dilakukan proses survei dan penegasan arah kiblat.

\section{Tinjauan Pustaka}

Menghadap arah Kiblat merupakan suatu ketentuan yang penting dalam syariah Islam. Menurut hukum syariat, menghadap ke arah kiblat diartikan sebagai seluruh tubuh atau badan seseorang menghadap ke arah Ka'bah yang terletak di Makkah al Mukarramah yang merupakan pusat tumpuan umat Islam bagi menyempurnakan ibadah-ibadah tertentu. Menghadap ke arah kiblat menjadi syarat sah bagi umat Islam yang hendak menunaikan shalat.

Kaidah dalam menentukan arah kiblat memerlukan suatu ilmu khusus yang dipelajari atau sekurang-kurangnya meyakini arah yang dibenarkan agar sesuai dengan syariat. Dalam kegiatan survei pemetaan, pergeseran $1^{\circ}$ di daerah khatulistiwa Indonesia, akan mengakibatkan pergeseran arah sekitar $111 \mathrm{~km}$. Hal tersebut berarti bahwa kesalahan sebesar $1^{\circ}$ dalam menentukan arah kiblat, dapat menjadikan arahnya menyimpang sejauh $111 \mathrm{~km}$ dari Ka'bah.

Penentuan arah kiblat secara tradisional menggunakan petunjuk alam seperti Matahari Terbit dan Terbenam, Fase Bulan, Rasi Bintang, Cahaya Fajar bahkan menggunakan Arah Angin 
telah dilakukan oleh masyarakat Islam sejak setelah zaman kenabian pada abad ke-5. Namun setelah abad ke-7 kaidah tersebut berkembang dengan adanya penemuan ilmu pengetahuan yang dapat menentukan arah kiblat secara lebih tepat. Diantara ilmuwan Islam yang telah melakukan perhitungan arah kiblat ialah Al Khawarizmi (780-850), Al Batani (858-929), Abu Al Wafa Al Buzjani (940-997), Ibnu Al Haitam (965-1040), Al Biruni (973-1048), Al Tusi (1201-1274), Habsah Al Hasib (850), Al Nayrizi (897), Ibnu Yunus (985), Al Khalili (1365) dan Al Shatir (1306-1375). Masa itu telah berkembang perhitungan arah kiblat menggunakan kaidah matematika trigonometri. Bahkan pada awal abad ke-9 telah dilakukan pengukuran koordinat kota Mekah dan kota Baghdad untuk menentukan arah kiblat kota Baghdad (Arkanuddin, 2010).

Dengan seiring berkembangnya teknologi, termasuk diantaranya teknologi survei dan pemetaan seperti penggunaan Total Station (TS) dan GNSS (Global Navigation Satellite System), penentuan arah kiblat menjadi lebih mudah dan akurat. Menurut Arkanuddin (2010), untuk melakukan perhitungan terhadap arah kiblat dengan teliti maka kita harus mengenal Ilmu Matematika Geodesi, khususnya dalam Segitiga Bola yaitu ilmu ukur sudut bidang datar yang diaplikasikan pada permukaan berbentuk bola. Metode penentuan arah kiblat ini pertama kali dikembangkan para ilmuwan muslim dari Jazirah Arab seperti Al Battani dan Al Khawarizmi dan terus berkembang hingga kini menjadi salah satu ilmu Geodesi.

Sebagaimana pendapat umum bahwa yang disebut arah atau syatrah adalah "jarak terpendek" berupa garis lurus ke suatu tempat sehingga Kiblat juga menunjukkan arah terpendek ke Ka'bah. Karena bentuk Bumi yang bulat, garis ini membentuk busur besar sepanjang permukaan Bumi. Lokasi Ka'bah berdasarkan pengukuran menggunakan GPS maupun menggunakan software Google Earth secara astronomis berada di $21^{\circ} 25^{\prime} 21.04^{\prime \prime}$ Lintang Utara dan $39^{\circ} 49^{\prime} 34.04^{\prime \prime}$ Bujur Timur. Untuk mengetahui arah kiblat dari sebuah tempat di permukaan Bumi digunakan acuan segitiga bola sebagai berikut:

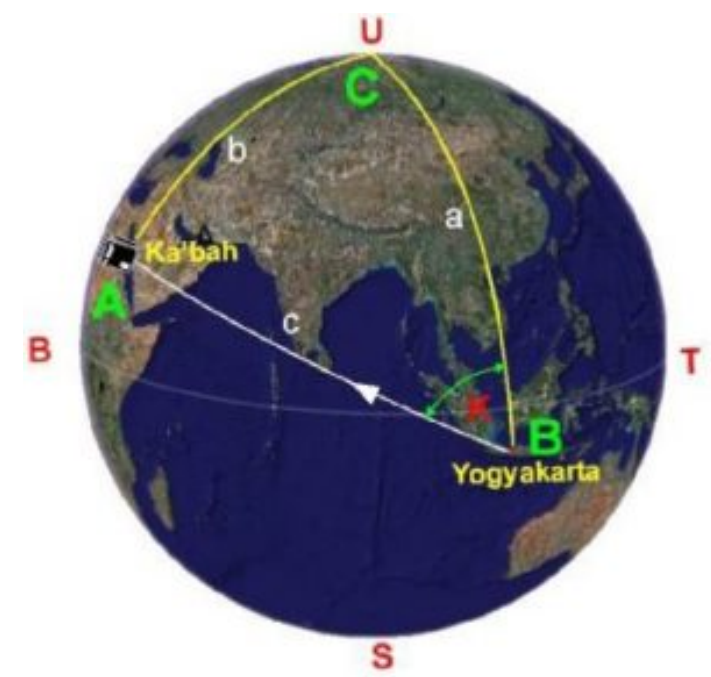

Gambar 1. Penerapan Segitiga Bola untuk Penentuan Arah Kiblat (Arkanuddin, 2010) 
Untuk perhitungan arah kiblat, ada 3 buah titik yang harus dibuat, yaitu titik A (posisi di Ka'bah (Mekah)), titik B (posisi tempat yang akan ditentukan arah kiblatnya), dan titik C (posisi di titik Kutub Utara). Titik A dan titik $\mathrm{C}$ adalah dua titik yang tetap, karena titik A tepat di Ka'bah dan titik $\mathrm{C}$ tepat di kutub Utara sedangkan titik B senantiasa berubah tergantung lokasi mana yang akan dihitung arah Kiblatnya. Bila ketiga titik tersebut dihubungkan dengan garis lengkung permukaan bumi, maka terjadilah segitiga bola ABC seperti pada Gambar 1. Dari Gambar 1, dapat diketahui bahwa yang dimaksud dengan perhitungan Arah Kiblat adalah suatu perhitungan untuk mengetahui berapa besar nilai sudut $\mathrm{K}$ di titik B, yakni sudut yang diapit oleh sisi a dan sisi c (Arkanuddin, 2010).

Koordinat Ka'bah diketahui memiliki posisi $\varphi=21^{\circ} 25^{\prime} \mathrm{LU}$ dan $\lambda=39^{\circ} 50^{\prime} \mathrm{BT}$. Untuk menghitung sudut arah kiblat, maka perlu diketahui koordinat titik yang akan ditentukan arahnya, dan kemudian dihitung dengan menggunakan persamaan berikut:

$$
\operatorname{tg} K=\frac{\sin (\lambda t-\lambda K)}{\cos \varphi t \cdot \tan \varphi K-\sin \varphi t \cdot \cos (\lambda t-\lambda K)}
$$

Dimana:

$\mathrm{K} \quad=$ sudut arah kiblat dari utara ke barat

$\varphi K \quad=$ lintang $\mathrm{Ka}$ 'bah $\left(21^{\circ} 25^{\prime} \mathrm{LU}\right)$

$\lambda K=$ bujur Ka'bah $\left(39^{\circ} 50^{\prime} \mathrm{BT}\right)$

$\varphi t \quad=$ lintang tempat yang akan ditentukan arahnya

At = bujur tempat yang akan ditentukan arahnya

Dalam prakteknya angka arah kiblat ini diwakilkan dalam angka azimuth yaitu angka sudut putaran dihitung dari nol derajat di titik Utara Sejati berputar ke arah Timur. Setelah diketahui azimuth arah kiblat maka langkah selanjutnya adalah melakukan pengukuran. Pengukuran dapat dilakukan menggunakan alat ukur sudut azimuth seperti Kompas atau peralatan yang lebih teliti yaitu Theodolit atau Total Station.

Theodolit atau Total Station merupakan alat yang digunakan untuk mengukur sudut horizontal dan sudut vertical. Dengan berpedoman pada posisi dan pergerakan benda-benda langit misalnya matahari dan bulan sebagai acuan atau dengan bantuan satelit-satelit positioning, maka alat ini dapat digunakan untuk mengetahui arah secara presisi hingga skala detik busur (Syaikhu, 2010). Benda-benda langit tersebut digunakan untuk melakukan kalibrasi arah utara sejati pada Total Station sebelum digunakan untuk mengukur arah kiblat pada posisi yang dikehendaki (Sobirin, 2012). 


\section{METODE}

Kegiatan pengabdian dilaksanakan dengan membagi menjadi dua tahapan seperti pada Gambar 2, yaitu meliputi tahap persiapan dan tahap pelaksanaan.

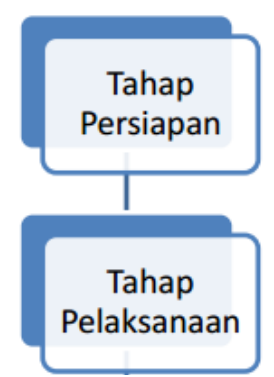

Gambar 2. Diagram Alir Pengabdian

Tahap persiapan meliputi survei pendahuluan, peninjauan lokasi, persiapan pengumpulan materi, mengumpulkan peralatan untuk pelaksanaan pengabdian masyarakat seperti Total Station, statif, kompas, dan lain sebagainya. Sementara itu tahap pelaksanaan dilakukan di lokasi pengabdian di daerah Pasir Panjang, Kota Batam. Kegiatan dimulai dengan sosialisasi penentuan arah kiblat dengan menggunakan teknologi survei dan pemetaan, dan kemudian dilanjutkan dengan kegiatan lapangan seperti pada Gambar 3.

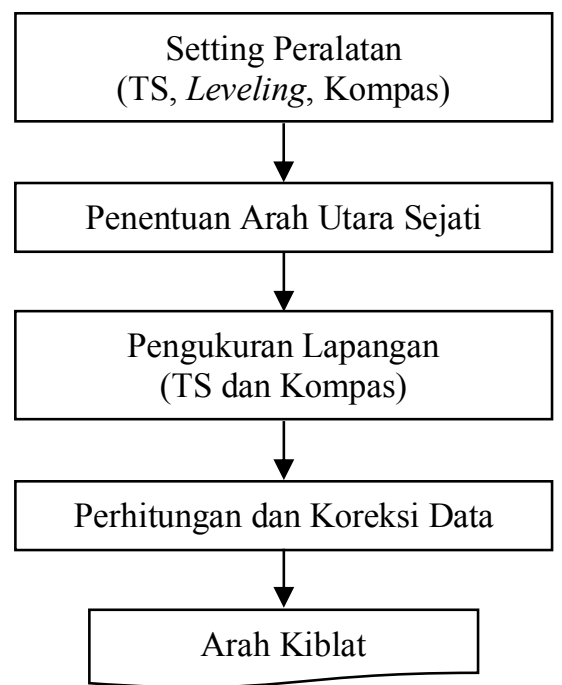

Gambar 3. Diagram Alir Pelaksanaan Kegiatan Lapangan

Kegiatan setting peralatan dilakukan untuk memastikan bahwa perlalatan yang dipakai telah terkalibrasi dengan baik, sehingga dalam penentuan arah utara sejati akan didapatkan hasil dan presisi dengan akurasi yang baik. Arah utara sejati dapat ditentukan dengan menggunakan kompas maupun matahari. Penggunaan kompas dapat dilakukan pada lokasi-lokasi yang tidak memiliki gangguan medan magnet, sedangkan azimuth matahari digunakan pada tempat dengan kondisi bayang-bayang matahari yang jelas. Arah utara sejati yang didapatkan kemudian akan 
digunakan untuk proses pengukuran arah kiblat. Secara terperinci kegiatan survei penentuan arah kiblat adalah sebagai berikut:

a) Membuat tanda titik di permukaan tanah atau lantai (misalnya titik $\mathrm{A}$ )

b) Membuka kunci knop horizontal kemudian mengarahkannya ke azimuth hasil perhitungan sebelumnya

c) Membuka kunci knop vertical kemudian mengarahkan TS ke permukaan tanah atau lantai (jarak kurang lebih 7 meter)

d) Membuat tanda titik kedua di permukaan tanah atau lantai yang bersinggungan atau bertepatan dengan garis silang dari frame target object (misalnya titik B)

e) Menarik benang atau tali dari titik A ke titik B, dan inilah arah kiblat yang dihasilkan.

\section{HASIL DAN PEMBahasan}

Tim Pengabdian kepada Masyarakat Jurusan Teknik Informatika Politeknik Negeri Batam pada hari Senin, 23 September 2019 melakukan kegiatan Pengabdian Masyarakat di Masjid Nurus Sabil Kampung Pasir Panjang, Kelurahan Rempang Cate, Kecamatan Galang, Kota Batam. Kegiatan pengabdian yang dilakukan berupa penentuan arah kiblat secara partisipatif.
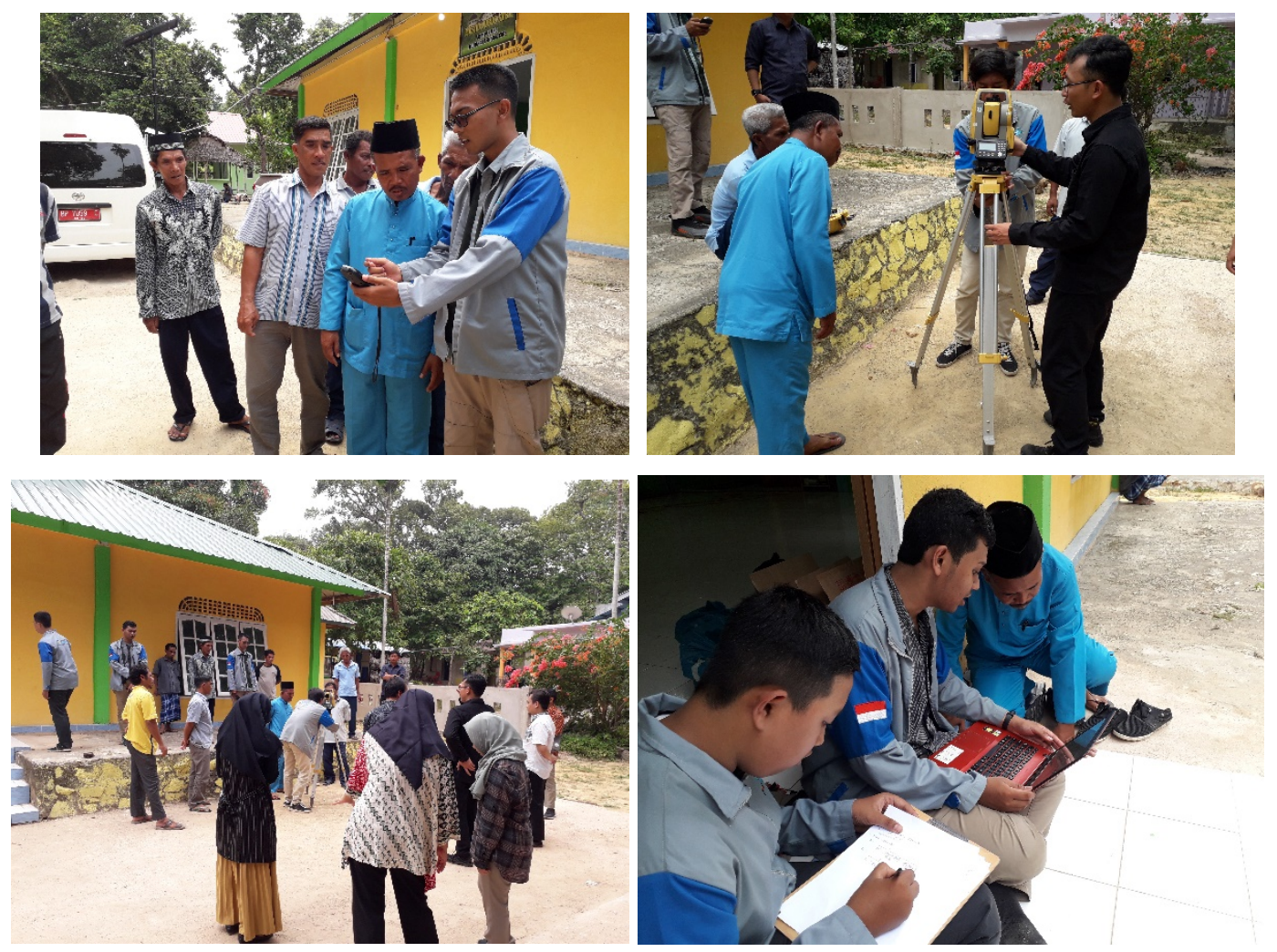

Gambar 4. Dokumentasi pelaksanaan penentuan arah kiblat secara partisipatif di Pasir Panjang 
Pelaksanaan kegiatan pengabdian dimulai dengan sosialisasi penentuan arah kiblat dengan menggunakan teknologi survei dan pemetaan, dan kemudian dilanjutkan dengan kegiatan lapangan yang melibatkan pejabat RW dan pengurus masjid untuk berpartisipasi secara langsung. Dikarenakan faktor cuaca yang kurang mendukung, maka metode penentuan arah kiblat dilakukan dengan metode segitiga bola.

Berdasarkan hasil perhitungan diperoleh sudut arah kiblat dari utara ke barat sebesar $66^{\circ}$ 50' 59.83" atau azimuth kompas sebesar $293^{\circ}$ 9' $0.17^{\prime}$ ". Hal itu menunjukkan bahwa terdapat perbedaan azimuth sebelum pengukuran $281^{\circ}$ dan setelah pengukuran $293^{\circ} 9^{\prime} 0,17^{\prime}$ ', atau berbeda sebesar $12^{\circ}$ dari azimuth/ arah kiblat awal masjid disana, dimana dari aawal berdirinya memang belum pernah dilakukan penetapan dan penegasan arah kiblat secara teliti.

Salah satu peserta yang berpartisipasi dari pihak pejabat RW kampung Pasir Panjang yaitu Wildan ketika diwawancarai mengatakan bahwa kegiatan pengabdian penentuan arah kiblat ini sangat mereka nantikan. Lebih lanjut, warga juga mengharapkan kegiatan penegasan dan pengukuran seperti ini juga dapat dilakukan terhadap musholla-musholla yang lain disekitarnya yang sampai pada tangal pengabdian tempo hari belum dilakukan penetapan arah kiblat.
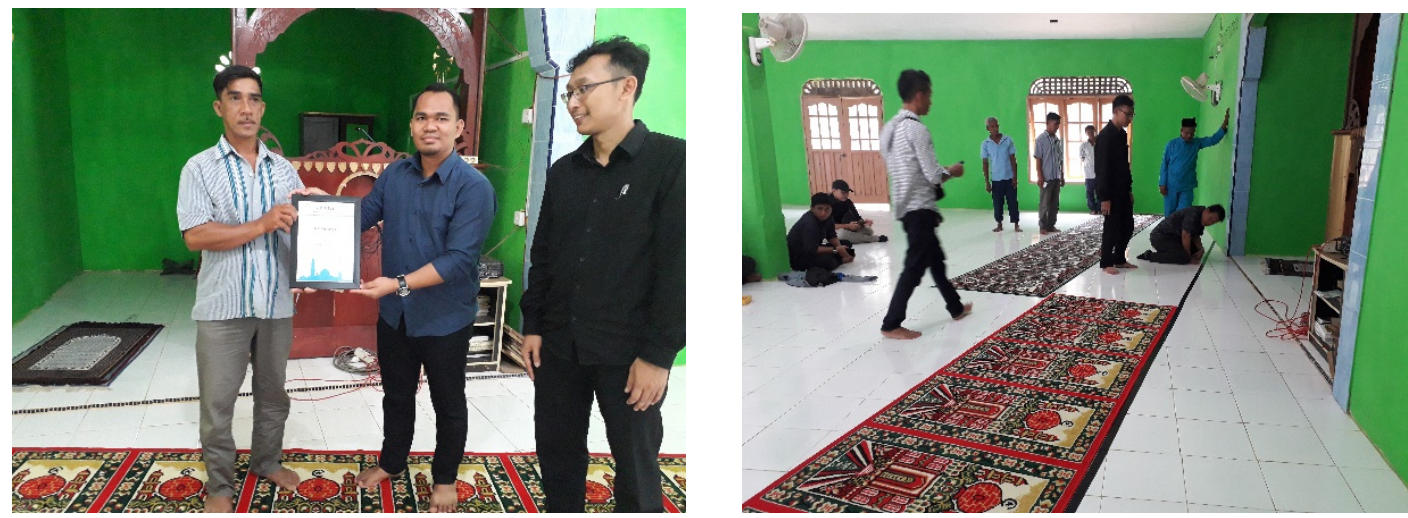

Gambar 5. Penyerahan secara simbolis sertifikat arah kiblat kepada perwakilan warga Pasir Panjang dan penetapan shaft sholat berdasarkan kiblat hasil ukuran

Hasil umpan balik yang diberikan terhadap peserta yang hadir secara keseluruhan mendapat nilai 100\% seperti pada Gambar 6, yang menunjukkan bahwa seluruh aspek mulai dari pemateri yang sesuai dengan bidang kompetensinya, fasilitas pendukung dalam penentuan arah kiblat secara partisipatif yang canggih dengan mengaplikasikan alat survei dan pemetaan modern dalam implementasinya serta kepuasan warga atas kegiatan ini yang benar-benar memberikan dampak terhadap kekhusyukan dalam beribadah kedepannya. Sebagai tambahan saran, warga juga mengharapkan kegiatan serupa dapat berlanjut untuk diimplementasikan pada mushollamusholla di lingkungan sekitarnya yang sampai saat ini belum pernah dilakukan penetapan arah kiblat secara resmi atau melalui suatu proses penerapan ilmu pengetahuan dan teknologi. Selain 
itu, kepuasan yang memiliki nilai sempurna ini juga dipengaruhi oleh jumlah responden yang kecil, yaitu 9 orang yang meliputi pejabat RW dan pengurus masjid Nurus Sabil. Hal ini juga mempengaruhi kecenderungan jawaban responden yang memilih nilai sempurna karena kegiatan ini tepat sasaran antara tema kegiatan dengan pesertanya.

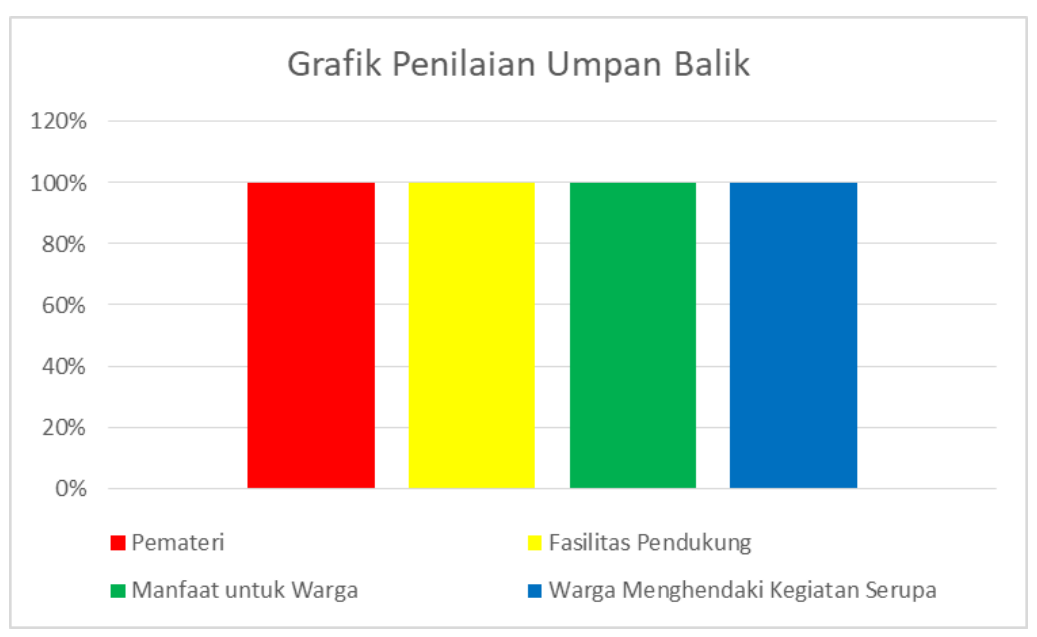

Gambar 6. Grafik penilaian umpan balik warga terhadap pelaksanaan kegiatan pengabdian masyarakat penentuan arah kiblat secara partisipatif kampung Pasir Panjang

\section{KeSIMPULAN}

Penentuan arah kiblat untuk kegiatan Pengabdian Masyarakat dilakukan dengan menggunakan metode perhitungan segitiga bola dimana data-data ukuran diperoleh dari pengukuran menggunakan GPS handheld, total station dan kompas magnetik. Dari pengukuran arah kiblat yang telah dilakukan di masjid Nurus Sabil, diperoleh sudut arah kiblat dari utara ke barat sebesar $66^{\circ} 50^{\prime} 59.83^{\prime \prime}$ atau azimuth kompas sebesar $293^{\circ} 9^{\prime} 0.17$ '. Berdasarkan hasil perhitungan tersebut terdapat perbedaan azimuth sebesar $12^{\circ}$ dari azimuth/arah kiblat awal masjid disana. Hal ini terjadi karena memang masjid tersebut dari awal berdirinya belum pernah dilakukan penetapan dan penegasan arah kiblat secara teliti dan resmi.

Hasil umpan balik melalui kuisioner secara keseluruhan mendapat nilai 100\%, yang mengartikan bahwasannya kegiatan pengabdian ini sangat bermanfaat, tepat guna dan diharapkan dilanjutkan lagi kedepannya.

\section{UCAPAN TERIMA KASIH}

Tim pengabdian mengucapkan terimakasih kepada Direktur Politeknik Negeri Batam beserta Pusat Penelitian dan Pengabdian Masyarakat (P3M) Politeknik Negeri Batam yang telah mendanai kegiatan pengabdian ini. Tim pengabdian juga mengucapkan terima kasih atas bantuan dan kerjasama rekan dosen yang memberikan saran, solusi, dan kritikan membangun agar pengabdian ini berjalan dengan lancar. 


\section{DAFTAR Pustaka}

Arkanuddin, Muthoha, 2010, Teknik Penentuan Arah Kiblat Teori dan Aplikasi, Lembaga Pengkajian dan Pengembangan Ilmu Falak (LP2IF) Rukyatul Hilal Indonesia (RHI).

Badan Pusat Statistik Kota Batam, 2018, Kecamatan Galang dalam Angka 2018, PT Revans Jaya Abadi, Batam.

Kencana, Yoga, 2014, Pemanfaatan Ilmu Geodesi untuk Menentukan Arah Kiblat, Universitas Diponegoro, Semarang.

Rassarandi, Farouki D, 2016, Pemetaan Situasi dengan Metode Koordinat Kutub di Desa Banyuripan, Kecamatan Bayat, Kabupaten Klaten, Jurnal Integrasi, Vol. 8, No. 1, April 2016, 50-55, Batam.

Sobirin, 2012, Penentuan Arah Kiblat Berdasarkan Azimuth Bulan (Studi Akurasi Arah Kiblat di Masjid Ulul Albab Universitas Islam Negeri Maulana Malik Ibrahim Malang), Skripsi, UNI Maulana Malik Ibrahim Malang.

Syaikhu, Ahmad, 2010, Metode Penentuan Arah Kiblat Dengan Teodolit (Pendekatan Sistem Koordinat Geografik Dan Ellipsoid), Semarang. 